DOI 10.19195/2084-2546.26.10

\title{
NATALIA SZEJKO
}

ORCID: 0000-0001-6160-9221

Uniwersytet Warszawski

Correo: natalia.szejko@gmail.com

\section{BARTOSZ DONDELEWSKI}

ORCID: 0000-0002-5570-6778

Uniwersytet Pedagogiczny w Krakowie

Correo: bartosz.dondelewski@up.krakow.pl

\section{“...andábame a amolar 0 «pensamento»..." - a voz dos excluídos en $A$ Esmorga de Eduardo Blanco Amor na véspera do nacemento do pensamento sociolingüístico galego}

Palabras chave: sociolingüística - A Esmorga - voz dos excluídos Mijail Bajtín — heteroglosia.

\section{Introdución}

Galicia sempre foi unha terra situada entre polos diferentes que corresponde sobre todo a estar no medio da cultura galega e castelá. Esta relación binaria significa, en primeiro lugar, o uso de dúas linguas diferentes que conducen á formación da identidade cultural. O poder das linguas e as consecuencias de exercer este poder ten repercusión na literatura. Un exemplo de como, a través do xogo linguístico-social, se demostran as relacións de poder cultural constitúeo a novela A Esmorga de Eduardo Blanco Amor. Na análise empregamos a noción do punto de vista de Mijail Bajtín y Jerzy Bartmiński, co afán de presentar o mundo da novela na percepción dos "esmorgantes". Ponse o enfoque na súa autopercepción e as capacidades comunicativas con outras camadas sociais máis altas castelan- 
falantes, cuxa lingua goza do prestixio lingüístico. Faise uso, ademais, da noción de heteroglosia do teórico literario ruso Mijail Bajtín ${ }^{1}$, analizando a distribución literaria das voces na novela e a importancia desta para construción da obra e creación do mundo literario. Bajtín ve na diversidade e multiplicación das voces o centro da novela, o enfoque principal que pode conducir a proliferación dos significados, como é no caso da Esmorga:

La novela es la diversidad social, organizada artistícamente, del lenguaje; y a veces, de lenguas y voces individuales. La estratificación interna de una lengua nacional en dialectos sociales, en grupos, argots profesionales, lenguajes de género; lenguajes de generaciones, de edades, de corrientes; lenguajes de autoridades, de círculos y modas pasajeros; lenguajes de los días, e incluso de las horas; social-políticos [...] constituye la premisa necesaria para el género novelesco ${ }^{2}$.

O noso obxectivo é tamén recalcar o carácter vangardista do pensamento presente no libro, que reflicte a estrutura social no uso da lingua e que demostra paralelismos coa escrita dos considerados pioneiros da sociolingüística galega: Ramón Piñeiro e Xesús Alonso Montero.

\section{Vida e obra de Eduardo Blanco Amor}

Eduardo Blanco Amor (1897-1979) foi un escritor e periodista que durante toda a súa vida escribiu nas dúas linguas: en galego e castelán, sen embargo, súa creación artística concentrouse sobre todo en Galicia e os problemas desta terra situada entre España e Portugal, entre terra firme e terra da emigración. Blanco Amor, como moitos outros escritores galegos, veuse obrigado a emigrar a Bos Aires, sen embargo, tamén dende alí seguiu contribuíndo ao desenvolvemento do seu país: foi director da revista Despertar Gallego fundada pola Federación de Sociedades Gallegas Agrarias e Culturales en Bos Aires. Posteriormente, colaborou con máis revistas tales como Terra, diario arxentino La Nación, Correo de Galicia, Revista de la casa de Galicia ou a famosa revista Nós. Durante a súa estancia en Arxentina coñeceu moitos escritores emblemáticos: Leopoldo Lugones, Horacio Quiroga, Jorge Luis Borges, Ernesto Sabato. Blanco Amor foi un escritor extremadamente prolífero, dedicouse á narrativa, poesía, ensaio, fotografía, tamén escribiu teatro en galego e en castelán. Moitas das súas obras narrativas ( $A$ Esmorga, Xente ao lonxe, Os biosbardos) desenvólvense nunha cidade ficticia, Auria, transposición literaria do seu Ourense natal. O estilo da súa obra pódese describir como hiperrealista, con algúns elementos expresionistas e esperpénticos, de aí as comparacións con Ramón de Valle-Inclán ou Eça de Queirós.

${ }^{1}$ M. Bajtín, Estética de la creación verbal, Buenos Aires, Siglo XXI, 2008.

${ }^{2}$ M. Bajtín, Problemas de la poética de Dostoievski, México, Fondo de Cultura Económica, 1988, p. 81. 


\section{A Esmorga como unha novela heteroglósica}

A Esmorga (1959) publicouse en Bos Aires, xa que debido ás restricións introducidas pola censura franquista, non foi posible distribuír a obra desde o inicio en Galicia. A obra concéntrase sobre todo nos personaxes pertencentes aos baixos fondos ourensáns. Os acontecementos teñen lugar nun espazo ficticio, a cidade de Auria, en Ourense. Cóntase historia dunha esmorga, unha festa buliciosa e esaxerada, en que participan tres personaxes transgresores e marxinais que van sendo levados a un final tráxico. Porén, esa experiencia tráxica cóntase dende unha perspectiva única, en realidade preséntanse só contestacións dun reo, participante da esmorga, durante o xuízo ao que foi subordinado. A única voz que acompaña as palabras do reo é a voz do xuíz, pero este fala castelán. A incomprensión entre galego e castelán indicase con o silencio simbólico de xuiz, mostrado con “...”. Dende o inicio participamos, entón, nun intercambio das voces pertencentes a diferentes capas sociais e diferentes ambientes lingüísticos. Os esmorgantes que destruían todo o que estaba ao seu alcance limitábanse durante a noite de esmorga a beber, vagar, roubar, violar e, finalmente, matar. A viaxe dos esmorgantes é un paso dende un sitio ao outro na busca de cada vez máis emocións extremas, pero é unha viaxe que acaba nunha traxedia.

Ao nivel de uso das técnicas literarias e temas que se poden identificar na obra de Blanco Amor, trátase da ruptura das tendencias costumistas e populares que dominaban anteriormente na literatura galega. Este cambio técnico débese ao afán de verosimilitude máxima, non soamente idem nivel de linguaxe realista, pero tamén cando se describen os acontecementos.

Por outro lado, como mencionamos anteriormente, A Esmorga é unha novela que se pode denominar como realista ou hiperrealista debido ao alto grao da naturalidade con que se describen os feitos:

O Bocas apareceu, erguéndose dun recanto, escuro, cos pantalós a medio subir, deixando ver a branca pele da barriga por un costado... E sen dicir palabra deste mundo, o Milhomes alancou para el e dun golpe afundiulle alí a navalla e rachou con ela para un lado, sacándoa aixiña para lle asegundar máis abaixo, con intención de ferilo nas súas partes, con perdón sexa dito. $\mathrm{O}$ Bocas cangouse para adiante querendo recoller coas maus escoadas de sangue, aquela trouxa de cousas branquiñosas que se verquían pola tremenda boca da ferida ${ }^{3}$.

Esta inclinación confróntase coa mirada subxectiva: a mirada de reo e de xuiz. A visión do mundo divídese en dous, dun representante de capas altas e dun de baixas. Esta mirada heteroxénea corresponde ao concepto de heteroglosia do teórico ruso Mijail Bajtín. Bajtín entendía o texto literario como unidade básica da comunicación verbal. Ao mesmo tempo, cada opinión, e cada mirada exposta no texto, non é neutra senón cargada de significado. É

\footnotetext{
${ }^{3}$ E. Blanco Amor, A Esmorga, Vigo, Editorial Galaxia, 2013, p. 104.
} 
na linguaxe onde Bajtín ve o inicio e punto de partida da heteroglosia que se pode executar a través de:

dialectos sociales, el comportamiento del grupo característico, jergas profesionales, lenguajes genéricos, lenguajes de generaciones y grupos de edad, los lenguajes tendenciosos, lenguajes de las autoridades, de diversos círculos y de modas pasajeras ${ }^{4}$.

O enunciado, en consideración de Bajtín, abre un número dado de posibilidades interpretativas e semánticas, revela o camiño da verdade entendida como proliferación das miradas:

Por eso, un enunciado revela una especie de surcos que representan ecos lejanos y apenas perceptibles de los cambios de sujetos discursivos, de los matices dialógicos y de marcas limítrofes sumamente debilitadas de los enunciados que llegaron a ser permeables para la expresividad del autor. El enunciado, así, viene a ser un fenómeno muy complejo que manifiesta una multiplicidad de planos ${ }^{5}$.

As voces que se presentan na novela non son voces situadas no baleiro, senón que están ligadas a un ambiente determinado. É máis, Bajtín subliña que unha voz nunca pode existir dentro do baleiro. Debería estar situada entre dous puntos do proceso de comunicación: entre o falante e o receptor da palabra falada ou escrita: "La significación puede llegar a existir sólo cuando dos o más voces se ponen en contacto: la voz de un oyente responde a la voz de un hablante" . A comprensión dun enunciado implica un proceso no que outros enunciados entran en contacto e o confrontan. Esta comprensión consiste en vincular a palabra do falante a unha contrapalabra. Comprender o enunciado doutra persoa significa orientarse con respecto a este enunciado, encontrar o lugar correcto para este, no contexto correspondente. A comprensión é para o enunciado o que unha liña de diálogo é para a seguinte.

As palabras constitúen entón das sprachliche Weltbild ${ }^{7}$, ou sexa partículas que forman o mundo ficticio. Pero as palabras poden crear e mudar o mundo real, según a teoría cognitivista do etnolingüista polaco Jerzy Bartmiński ${ }^{8}$. A súa teoría da visión do mundo dende a lingua é unha interpretación da realidade — verbalizada de diferentes maneiras - que se pode condensar baixo a forma de conxunto de opinións sobre o mundo. As opinións poden ser "fixas" na gramática, vocabulario, frases ditas, etc., pero existen tamén opinións "pre-

${ }^{4}$ M. Bajtín, Problemas de la poética de Dostoievski.., p. 289.

5 Ibidem, p. 283.

${ }^{6}$ Ibidem, pp. $256-257$.

${ }^{7}$ Das sprachliche Weltbild - a imaxe lingüística do mundo, concepto introducido no século XVIII e XIX por filósofo alemán Johann Georg Hamann. Refírese ao concepto en que a lingua inflúe a percepción do mundo e, ao revés, a percepción do mundo modera a lingua.

8 J. Bartmiński, "Punkt widzenia, perspektywa, językowy obraz świata”, en: J. Bartmiński (ed.), Językowy obraz świata, Lublin, Wydawnictwo UMCS, 1990, pp. 109-127, e idem, "Perspektywa, punkt widzenia, językowy obraz świata", en: J. Bartmiński et al. (eds.), Językowy obraz świata, Lublin, Wydawnictwo UMCS, 2004, pp. 103-120. 
supostas" isto é, implicadas polas formas lingüísticas perpetradas na sabiduría popular, nas actitudes, mitos, ritos e prexuízos.

A heteroglosia de Bajtín preséntase entón na Esmorga a través da introdución de dúas voces: a voz de xuíz e a do reo. O silencio do xuíz representa a xordeira da xustiza, pero tamén o seu papel represor e castigador. Son os discursos que falan e así conducen á formulación dos significados: creación de personaxes e ambientes nos que eses personaxes están situados. A voz do reo, como a voz predominante, crea a realidade, transmítea dentro do discurso monoglósico que constitúe, entón, o discurso creador do mundo, pero non necesariamente significa unha toma de responsabilidade, xa que: "Que han de ser disculpas! Eu non teño ren de que me disculpar que eu nada fixen, pois a ollar as cousas que pasan diante dun non é culpa dun, por máis que llas apoñan ou que llas queiran apoñer"9.

Se analizamos con máis profundidade a distribución das voces dentro do discurso narrativo da Esmorga, pódense identificar máis puntos dos que parte a enunciación. A novela comeza coa voz do narrador-autor, xa que na primeira parte da introdución propóñense presentar unha documentación obxectiva do que ocorreu: "Cando eu era aínda moi rapaz, seguíase a falar do caso entre as boas xentes de Auria, cibdá onde nascín e onde as cousas ocurriran. O caso contábase de moitos xeitos pro todos vińan a casar no final, que decote era o mesmo" 10 .

Un intento de obxectivación constitúe tamén a introdución da linguaxe da rúa, da vida cotiá que representa o reo. Por outra banda, o xuíz mostra, a través do silencio o poder da palabra muda:

- Non señor, non lle foi eisí como está nise papel que leron, que os papeis teñen conta do que lle poñen enriba, anque non foi moito o que entendín ${ }^{11}$.

Outro tipo de enunciación que se entrecruza co discurso realista son os poucos momentos da mirada poética ao mundo presentado que, a pesar do seu carácter naturalista sempre está situado na fronteira da realidade e o pesadelo irreal, do imposible de pasar e comprender. De alí que os feitos descritos teñen que permanecer no mundo da noite, que simboliza, neste caso, a entrada cara ao subconsciente, cara ao Id, que queda normalmente subordinado ao control do Ego e o Superego:

Pro o que pasou á noite... a noite está ateigada de cousas, todas tan xuntas que mesmo me somella que non puido habere tempo para tanto, coma si foran moitas noites xuntas, unhas a cabo de outras, ou unha noite moi longa, sen día no entremeio; ou como cousas desaceitadas, sen antes nen dempois, que nin eu mesmo me entendo... a máis diso, tiven moitas vegadas o

\footnotetext{
${ }^{9}$ E. Blanco Amor, op. cit., p. 23.

${ }^{10}$ Ibidem, p. 1.

11 Ibidem, p. 8.
} 
“pensamento", que me veu moi seguido, e daquela é coma si me ceibasen do tempo e de todo, coma si estivese e non estivese... 12

Como protagonistas de Eyes Wide Shut de Stanley Kubrick, os personaxes de Blanco Amor tamén participan nunha viaxe simbólica cara ao centro da súa personalidade: esa viaxe é unha mostra do oprimido, pero desexado, do controlado que agora xa non pode estar baixo control algún. Sen embargo, os protagonistas de Eyes Wide Shut xogan coa súa propia identidade para explorar o seu mundo interior, mentres que na Esmorga estamos ante un proceso de presentación de si mesmo en comportamento forzado polos factores exteriores e unha desafortunada combinación de eventos.

O reo da Esmorga tamén é vixiante nocturno: o home quen revela a verdade dos soños que se converten en realidade, canalízanse nunha serie de acontecementos infortunios, pero liberadores. Ao participar no tráxico entende mellor o seu propio comportamento, o extremo revela os sentimentos verdadeiros.

\section{Blanco Amor na vangarda do pensamento sociolingüístico galego}

Comentado isto, quixeramos chamar a atención non só ao importante papel que tivo o personaxe de Blanco Amor para o legado artístico e literario de Galicia, senón tamén ao carácter vangardista da diagnose social presentada nas cartas d'A Esmorga, que parece non estar lonxe da presentada polos escritos académicos que naquel momento introducían a (aínda nacente) sociolingüística na ciencia galega. Na opinión de Rei-Doval ${ }^{13}$, o período pre-inicial desa póla da ciencia da linguaxe en Galicia comprende o tempo entre 1967, publicación da obra "A linguaxe e as linguas" de Piñeiro, e o final da época franquista. Pretendemos identificar os elementos da diagnose da sociedade e do rol da lingua galega que $A$ Esmorga comparte coa de Ramón Piñeiro e Xesús Alonso Montero e propor recoñecer a obra de Blanco Amor como unha das primeiras premisas do inminente nacemento da sociolingüística, que apoiaron e provocaron o debate sobre a intersección lingua-sociedade no galego e en Galicia, antes da década dos 70, comezo do establecemento da ciencia chamada sociolingüística, con todo o seu aparato teórico-metodolóxico, representada en Galicia por nomes tales como M. Rodríguez Neira, M. Fernández, G. Rojo ou X. Rubial. Aínda que nin Piñeiro, nin Alonso Montero se poden considerar sociolingüistas no sentido que lle damos á palabra hoxe en día,

12 Ibidem, p. 24.

13 G. Rei-Doval, "Sociolingüística gallega y sociolingüística luso-hispánica: conexiones e influencias”, en: A. Valencia-Espinoza (ed.), Actas del XIV Congreso Internacional de la Asociación de Lingüistica y Filología de América Latina (ALFAL), Santiago de Chile, Alfal, 2006. 
máis que nada porque a súa obra data da época cando as ferramentas metodolóxicas e teóricas propias da disciplina apenas comezaran a estar sendo forxadas, os estudosos si poden ser relacionados cos primeiros intentos que máis tarde desembocarían no que hoxe chamamos a sociolingüística ${ }^{14}$.

$\mathrm{O}$ ensaio A linguaxe e as linguas ${ }^{15}$ foi pronunciado por Ramón Piñeiro o 25 de novembro de 1967 como discurso de ingreso na Real Academia Galega. Segundo Henrique Monteagudo, quen escribiu o limiar para a nova edición, o discurso pódese considerar "o primeiro abrollo da sociolingüística galega"16, Aínda que faltan probas de que Piñeiro coñecese directamente os primeiros traballos de William Labov, considerado un dos fundadores da sociolingüística, algúns dos aspectos que comenta Piñeiro parécense coas ideas presentadas polo estadounidense ${ }^{17}$. Rei-Doval supón tamén que Piñeiro podería ter coñecido as ideas primitivas dese novo enfoque a través dos seus contactos cos intelectuais cataláns relacionados coa filosofía e as ciencias sociais. Sabemos, por exemplo, que o ilustre galego leu o traballo Lingüistica e colonialismo de Louis-Jean Calvet e coñecía os debates actuais sobre a diglosia, o bilingüismo e o conflito lingüístico ${ }^{18}$.

Xesús Alonso Montero, representante dunha xeración máis nova, un intelectual ávido e inquieto, estivo ao corrente dos debates mantidos no eido daquela nacente vertente lingüística, o que proba o seu Informe —dramático- sobre la lengua gallega ${ }^{19}$, obra de grande acollimento entre o público interesado pola situación social do galego. A súa redacción acompaña o desenvolvemento da sociolingüística catalá con Rafael Ninyoles como o seu sumo representante. É a través das traducións - ás veces defectuosas, como demostra Rei Doval ${ }^{20}$ - feitas polo último que incorpora Alonso Montero algunhas ideas de Fishman e Ferguson, outros fundadores da sociolingüística estadounidense e mundial.

No texto de Piñeiro, atopámonos cunha condena da represión lingüística apuntando o autor ao réxime franquista coma o seu actor ${ }^{21}$. Introdúcense

${ }^{14}$ Cf. por exemplo: M. Fernández, "Los orígenes de la Sociolingüística", en: M. Casas Gómez (dir.), J. Espinosa García (ed.), II Jornadas de Lingüistica, Cádiz, Servicio de Publicaciones de la Universidad de Cádiz, 1997; G. Rei-Doval, "A sociolingüística galega no contexto hispánico: conexións e influencias", en: H. González, M. X Lama (eds.), Actas do VII Congreso Internacional de Estudos Galegos. Mulleres en Galicia. Galicia e os outros pobos da Península, Barcelona 28 ó 31 de maio de 2003, Ediciós do Castro / Asociación Internacional de Estudos Galegos (AIEG), 2003; G. Rei-Doval, "Ramón Piñeiro, sociolingüista avant la lettre", en: A. Santamarina (ed.), Ramón Piñeiro: Día las Letras Galegas 2009, Santiago de Compostela, Universidade, Servizo de Publicacións e Intercambio Científico, 2009.

${ }^{15}$ R. Piñeiro, A linguaxe e as linguas, Vigo, Editorial Galaxia, 2007 [1967].

${ }^{16}$ Ibidem, p. 23.

17 G. Rei-Doval, “A sociolingüística galega no contexto hispánico...”, op. cit.

18 Ibidem.

19 X. Alonso Montero, Informe - dramático - sobre la lengua gallega, Madrid, Akal Editor, 1973.

${ }^{20}$ G. Rei-Doval, “A sociolingüística galega no contexto hispánico...,, op. cit.

${ }^{21}$ R. Piñeiro, op. cit., pp. 21-22. 
tamén dous termos: prexuízo e prestixio. Piñeiro considera que as causas da prostración do galego radican na prevalía de tres tipos de prexuízos: sociolóxico, lingüístico e ideolóxico. En A Esmorga observamos o prexuízo sociolóxico no contacto dos protagonistas co xuíz, coa Lola a viguesa ou co enxeñeiro madrileño: o idioma serve de base para a distinción por parte das clases privilexiadas e coma ferramenta de discriminación das clases inferiores, o que ten consecuencias no complexo de inferioridade e na separación entre as elites e o pobo miúdo, condenado á aceptación resignada da súa inferiorida$\mathrm{de}^{22}$. Opina Piñeiro: "O feito de que durante varios séculos o galego teña sido arredado de toda vixencia oficial e reducido á condición de lingua oral popular tiña que producir - e produciu, claro está- unha profunda discriminación sociolóxico-idiomática" 23 .

A realidade descrita na novela reflíctese tamén no Informe - dramáticosobre la lengua gallega de Alonso Montero, onde se diagnostica a substitución lingüística do galego a favor do castelán ${ }^{24}$ : na novela, as posturas dos protagonistas revelan o alto prestixio do castelán, lingua na que, naqueles anos, optaban por falarlles aos fillos os pais que querían aumentar as súas posibilidades de ascenso social. Os protagonistas, incapaces de pronunciárense na lingua do Estado, tratan de distanciarse do poder opresor dos castelanfalantes a través da burla: "[...] outras das casas de a peso que falan castrapo cheio de jeadas para facérense as finas e as madrileñas cos señoritos da vila" 25 . Outro exemplo da distancia entre o pobo miúdo e os representantes da elite social castelanfalante é a escena das festas que acostumaban a organizar os empregados dos donos do Pazo na ausencia dos últimos ${ }^{26}$. O seu desexo imperioso de fartarse coa comida e bebida revela unha vida levada na extrema pobreza. O simulacro no cal se transforman en señores, é sinal do seu desexo de mudanza social. Coma opina Forcadela, "[a] burla que levan a cabo oculta a súa vinganza pero tamén a súa envexa"27.

\section{Conclusións}

A Esmorga é un retrato da clase social máis baixa sen dereitos, condenada a permanecer calada e desfavorecida ante o poder do estado, ante unha opresión verbalizada (ou implícita) na lingua castelá. Nas últimas liñas do seu ensaio, di Ramón Piñeiro:

${ }^{22}$ Ibidem, pp. 75-76, 78, 81.

23 Ibidem, p. 76.

${ }^{24}$ X. Alonso Montero, op. cit., pp. 143-145.

25 E. Blanco Amor, op. cit., p. 59.

26 Ibidem, pp. 42-43.

${ }^{27}$ M. Forcadela, Guía de lectura de A Esmorga de Eduardo Blanco Amor, Vigo, Edicións do Cumio, 1991, p. 40. 
Somos unha das formas de expresión do pulo creador da vida humana. Porque somos un pobo dotado dunha lingua e, polo mesmo, dunha cultura, somos unha realidade orixinal dentro do patrimonio humano. A nosa misión consiste en facer que esa realidade orixinal acade a súa plenitude ${ }^{28}$.

Parécenos que, de lelo, firmaríao tamén Blanco Amor. Na novela preséntanse elementos de diagnose da estrutura e dos mecanismos sociais que - pasados máis ou menos tres lustros - serán descritos polos considerados pioneiros da sociolingüística galega. Blanco Amor acerta en identificar as cuestións que en breve formarán o núcleo dos debates sociolingüísticos en Galicia: os prexuízos ou estereotipos lingüísticos seculares existentes en condicións dunha marcada diglosia, co castelán como a lingua do poder estatal e de alto prestixio social, e o galego como a dos estratos máis baixos, desfavorecidos económica e socialmente.

Ao mesmo tempo, A Esmorga é unha novela na que se presenta unha mirada heterotópica do mundo dividido en dúas voces e miradas, na que os esmorgantes chegan ao extremo do comportamento humano pero a través do encontro co límite atopan unha linguaxe nova, a linguaxe da verdade. Ao mesmo tempo, de acordo coas teorías de Mijaíl Bajtín, soamente na mirada ampla, aberta á multiplicidade das voces, é posíbel escapar do reducionismo e ampliar o horizonte de expectativas. Isto débese sobre todo a especificidade do xénero novelesco e o seu afán de concretar o mundo creado a través da escolla de falante e a palabra usada por ese. Sen embargo, a palabra está sempre representada dentro do marco artístico dado, nunca é un discurso puro do protagonista presentado. Por outra banda, o protagonista permanece sempre un home social, determinado polo entorno que lle rodea. Ao final da conta, o que determina, entón, a mensaxe da novela é a interrelación entre a palabra e o home que a dirixe, creando un tipo de ideoloxemas específicos para súa situación nun momento dado da historia:

El hablante en la novela siempre es, en una u otra medida, un ideólogo, y sus palabras siempre son ideologemas. Un lenguaje especial en la novela es siempre un punto de vista especial acerca del mundo, un punto de vista que pretende una significación social ${ }^{29}$.

\section{Referencias bibliográficas}

\section{ALONSO MONTERO Xesús}

1973 Informe —dramático - sobre la lengua gallega, Madrid, Akal Editor.

BAJTÍN Mijail

1988 Problemas de la poética de Dostoievski, México, Fondo de Cultura Económica. Trad. Tatiana Bubnova.

2008 Estética de la creación verbal, Buenos Aires, Siglo XXI. Trad. Tatiana Bubnova.

\footnotetext{
${ }^{28}$ R. Piñeiro, op. cit., p. 96.

${ }^{29}$ M. Bajtín, Problemas de la poética de Dostoievski..., p. 150.
} 


\section{BARTMIŃSKI Jerzy}

1978 O derywacji stylistycznej. Gwara w funkcji języka artystycznego, Lublin, Wydawnictwo UMCS.

1990 "Punkt widzenia, perspektywa, językowy obraz świata”, en: Bartmiński J. (ed.), Językowy obraz świata, Lublin, Wydawnictwo UMCS, pp. 109-127.

2004 "Perspektywa, punkt widzenia, językowy obraz świata", en: Bartmiński et al. (eds.), Językowy obraz świata, Lublin, Wydawnictwo UMCS, pp. 103-120.

BLANCO AMOR Eduardo

2013 A Esmorga, Vigo, Editorial Galaxia.

CAMPOS RODRÍGUEZ Vanessa B.

2001 "Más allá del espejo. Análisis del film Eyes Wide Shut de Stanley Kubrick", Trama y Fondo, 1, p. 01, versión virtual: http://www.tramayfondo.com/, 1.03.2016.

ESCRIU Alba

2012 "The Portrayal of the Gaze Through Eyes Wide Shut", en: Martín Alegre S. (coord. and ed.), Moyer M. (ed.), Pladevall E. (ed.), Tubau S. (ed.), At a Time of Crisis: English and American Studies in Spain, Barcelona, Departament de Filologia Anglesa i de Germanística, Universitat Autònoma de Barcelona/AEDEAN.

FERNÁNDEZ Mauro

1997 "Los orígenes de la Sociolingüística”, en: Casas Gómez M. (dir.), Espinosa García J. (ed.), II Jornadas de Lingüistica, Cádiz, Servicio de Publicaciones de la Universidad de Cádiz.

FORCADELA Manuel

1991 Guía de lectura de A Esmorga de Eduardo Blanco Amor, Vigo, Edicións do Cumio.

MONTEAGUDO Henrique

1999 Historia social da lingua galega, Vigo, Editorial Galaxia.

PIÑEIRO Ramón

2007 [1967] A linguaxe e as linguas, Vigo, Editorial Galaxia.

REI-DOVAL Gabriel

2003 “A sociolingüística galega no contexto hispánico: conexións e influencias”, en: González H., Lama M. X. (eds.), Actas do VII Congreso Internacional de Estudos Galegos. Mulleres en Galicia. Galicia e os outros pobos da Península, Barcelona 28 ó 31 de maio de 2003, Ediciós do Castro / Asociación Internacional de Estudos Galegos (AIEG).

2006 "Sociolingüística gallega y sociolingüística luso-hispánica: conexiones e influencias”, en: Valencia-Espinoza A. (ed.), Actas del XIV Congreso Internacional de la Asociación de Lingüistica y Filología de América Latina (ALFAL), Santiago de Chile, Alfal.

2007 A lingua galega na cidade no século XX. Unha aproximación sociolingüística, Vigo, Edicións Xerais.

2009 "Ramón Piñeiro, sociolingüista avant la lettre", en: Santamarina A. (ed.), Ramón Piñeiro: Día las Letras Galegas 2009, Santiago de Compostela, Universidade, Servizo de Publicacións e Intercambio Científico.

SAPIR Edward

1978 Kultura, język, osobowość, trad. de B. Stanosz, R. Zimand, Warszawa, Państwowy Instytut Wydawniczy.

VILAVEDRA Dolores

1994 "A esmorga: un exemplo da rendabilidade da polifonía como estratexia enunciativa nas literaturas minorizadas", en: Paz Gago J.M., Fernández Roca J.Á., Gómez Blanco C.J. (eds.), Semiótica y modernidad. Actas del V Congreso internacional de la Asociación Española de Semiótica (A Coruña, 1992), A Coruña, Universidade, Servizo de publicacións.

WHORF Benjamin Lee

2002 Język, myśl i rzeczywistość, trad. de T. Hołówka, Warszawa, Wydawnictwo KR. 


\section{"...andábame a amolar 0 "pensamento"..." - the voice of the excluded in A Esmorga by Eduardo Blanco Amor in the eve of the sociolinguistic reflexion in Galicia}

Keywords: Sociolinguistics - A Esmorga — voice of excluded — Mikhail Bakhtin — heteroglossia.

\section{Abstract}

Goals: In this paper we analyse the sociolinguistic situation of the Galician-speaking representatives of the bottommost social class just after the Spanish Civil War (the 50's). This context is depicted in the novel A Esmorga of E. Blanco Amor. We introduce the notion of point of view (Bakhtin, Bartmiński) in order to analyse the world portrayed in the novel through the perception of the proper "esmorgantes".

Methodology: Analysis of the distribution of voices in A Esmorga and its sociolinguistic repercussions according to the theory of polyglossia of Mikhail Bakhtin and Das sprachliche Weltbild of E. Sapir and B. Whorf. Comparison of the vision of the world presented by Blanco Amor with the sociolinguistic insights of R. and X. Montero.

Results: The voices in the novel are divided into the voice of power of the judge and the oppressed voice of the accused as a conscious election in which the word is given to the excluded.

Conclusions: A Esmorga is a novel in which the reader finds a heterotopic vision of the world, divided between two voices and viewpoints. The esmorgantes reach the limits of human behaviour, although through this bordering experience they encounter a new language, the language of the truth.

Fecha de recepción: 12.09.2017

Fecha de aceptación: 7.02.2018 